\title{
Does short-term oxygen depletion affect predator-prey relationships in zoobenthos? Experiments with the isopod Saduria entomon
}

\author{
Eva Sandberg
}

Husö Biological Station, Department of Biology, Åbo Akademi University, SF-20520 Åbo, Finland

\begin{abstract}
Periodic oxygen deficiency as a secondary effect of eutrophication has become more frequent in coastal zones of the northern Baltic Sea. As a sublethal effect oxygen deficiency may affect important functions in the zoobenthic community, e.g. predator-prey relationships. A method for studying change in predation efficiency of the predatory isopod Saduria entomon (L.) under oxygendeficient conditions was developed and applied in a series of aquarium experiments with $S$. entomon as predator and the amphipods Corophium volutator Pallas and Bathyporeia pilosa Lindström as prey organisms. C. volutator represents less-active (with respect to swimming) species while $B$. pilosa is more active. The experiments with S. entomon and C. volutator were performed in 95, 50, 30 and $17 \%$ oxygen saturation, and those with $S$. entomon and B. pilosa in 95, 50 and $35 \%$ saturation. S. entomon preyed significantly $(p<0.01)$ on $C$. volutator except at the $17 \%$ oxygen level. S. entomon had a significant effect on $B$. pilosa in $95 \%(p<0.01)$ and $50 \%(p<0.05)$ oxygen saturation but the predation effects were significantly reduced in $35 \%$ oxygen. These results indicate the existence of oxygen threshold values where predation efficiency of $S$. entomon declines depending on the prey species. Changes in predation rates may alter prey population size and dynamics. In the species-poor Baltic Sea changes in predator-prey relationships may cause changes at the community level.
\end{abstract}

KEY WORDS: Oxygen deficiency · Saduria entomon · Predator-prey relationships - Baltic Sea

\section{INTRODUCTION}

Anthropogenic nutrient load in shallow coastal areas has increased over the last decade and the effects at the ecosystem level have become more evident (see Gray 1992 and references therein). The semi-enclosed, brackish Baltic Sea is, owing to its restricted horizontal and vertical water exchange, particularly susceptible to anthropogenic inputs (Nehring \& Matthäus 1991). Discharges of nutrients to the Baltic have increased considerably: from 10000 t of phosphorus and $300000 \mathrm{t}$ of nitrogen annually at the end of the 19th century to around 80000 and $1200000 \mathrm{t}$ respectively, today (Larsson et al. 1985). This leads indirectly to frequent hypoxic conditions in both the deeper and shallower areas (Cederwall \& Elmgren 1990). In the coastal regions that are particularly influenced by river discharges and direct inputs of waste-water and sewage, eutrophication is increasing rapidly, although in the Baltic basins deteriorated oxygen conditions in the near-bottom water and subsequent phosphate accumulation can be considered natural rather than anthropogenic (Nehring \& Matthäus 1991). The effects of eutrophication on zoobenthos in shallow, coastal areas (above the halocline) include an increase in abundance and biomass and a decrease in species number, inducing changes in the structure and function of benthic communities (Pearson \& Rosenberg 1978, Elmgren 1989, Bonsdorff et al. 1991). Below the halocline, oxygen deficiency may reduce total benthic biomass (Weigelt 1991). Since benthic organisms significantly amplify nitrification and denitrification processes by removing nitrogen as gas from the sea to the atmosphere (up to $50 \%$ removal; Seitzinger et al. 1984), defaunation induced by hypoxia can lead to a selfacceleration of the eutrophication process (Kemp et al. 1990). The ecological impacts of hypoxia or anoxia can be extensive but difficult to evaluate due to the inherent variability of natural biological communities, which respond continuously to the influence of a multitude of 
biological and environmental factors. Due to the lack of information regarding lethal and sublethal effects of low oxygen levels for many species, a clear understanding of biological impacts is still difficult to obtain (Winn \& Knott 1992). Weigelt (1991) considers oxygen deficiency the only event which has such drastic consequences for the benthos as total community breakdown. If the community does not undergo a complete breakdown, functionally important interactions can be expected to be disturbed. One behavioural response of benthic infaunal organisms to severe hypoxia and anoxia is that they emerge from the sediment (Jørgensen 1980). Pihl et al. (1992), in a study on the diet of bottom-feeding fish and crustaceans during hypoxia, found that the predators achieved optimal prey exploitation during or immediately after hypoxia. The gut contents of the predators contained significantly larger, deeper-burrowing prey. These changes in the sediment depth distribution of infauna, leading to increased prey availability to both transient and resident predators, may have an important impact on community structure and function (Rosenberg \& Loo 1988, Pihl 1989, Baden et al. 1990, Pihl et al. 1991). The response to oxygen deficiency at both the community and population level is dependent on exposure time, frequency and severity. Depending on the ability of a species to either escape or tolerate the stress of oxygen deficiency, and on the function of the species (prey or predator, trophic level), a different response at the community level is expected (Breitburg 1992). The present study was designed to test for changes in predation efficiency and predation rate of a predator-prey system experiencing oxygen deficiency at different levels. The aim was to obtain a better knowledge of changes in the relationship between a predator and its prey, i.e. in predation rate, due to increasing stress by decreasing oxygen levels. A gradual decrease in oxygen content was used to determine the possible threshold level at which the function (as prey or predator) ceases. Two different prey species were used to look for any possible impact of prey behaviour, here characterized by mobility (level of swimming activity).

\section{TEST ORGANISMS}

The isopod Saduria (Mesidotea) entomon (L.) is a euryhaline, invertebrate predator living in an environment with high risk of exposure to both hypoxia and anoxia, as it is found throughout the depth range of the Baltic Sea. It is one of the most important invertebrate predators in the Baltic (Leonardsson 1986, 1991, Sandberg \& Bonsdorff 1990,1993, Ejdung \& Bonsdorff 1992, Hill \& Elmgren 1992) and an important food item for fish (e.g. cod, flounder, sculpin; Leonardsson et al.
1988). Normally, S. entomon is completely buried in the bottom substratum and emerges for feeding, reproduction and migration. It has a nocturnal foraging activity pattern (Hill \& Elmgren 1992). This species is well suited to sustaining long periods of hypoxia due to its low respiratory level, increased haemocyanin concentration and carrying capacity when exposed to hypoxia, and respiratory alkalosis (increase in haemolymph $\mathrm{pH}$, probably increasing oxygen affinity; Hagerman \& Oksama 1985). It also tolerates prolonged anoxia (up to $300 \mathrm{~h}$, salinity $7 \%, 8^{\circ} \mathrm{C}$ ) due to a metabolic strategy adapted for anaerobic conditions (Hagerman \& Szaniawska 1990), and it is also able to survive exposure to sulphide by detoxifying $\mathrm{H}_{2} \mathrm{~S}$ in the midgut gland (Visman 1991).

Corophium volutator Pallas is an opportunistic, euryhaline amphipod ( 3 to $34 \%$ ) common on most soft bottoms. It is one of the most common and abundant species on the sheltered intertidal and shallow bottoms of northwestern Europe (e.g. Möller \& Rosenberg 1982). The organisms live buried in tubes where they obtain oxygen-rich water by ventilatory activity of their pleiopods. They feed on detritus or act as filterfeeders (Fenchel et al. 1975).

The amphipod Bathyporeia pilosa Lindström is a common inhabitant of sandy beaches and is extremely euryhaline (Mettam 1989). It is an active swimmer, tolerant of environmental stress and starvation (Mettam 1989). Because the Baltic Sea is non-tidal, $B$. pilosa is forced to live in sediments which are always covered by water; hence living conditions differ greatly from those in the intertidal zone (i.e. there is a greater risk of oxygen-depleted conditions). The oxygen demand of $B$. pilosa increases strongly with temperature (Fish \& Preece 1970) and therefore the oxygen content of the interstitial water is especially critical in summer (Nicolaisen \& Kanneworff 1983). The species feeds on sessile microbenthic diatoms and detritus (Dahl 1973).

Compared with Bathyporeia pilosa, Corophium volutator are less active, and swimming exhausts them within a short time (Jensen \& Kristensen 1990).

\section{MATERIALS AND METHODS}

General experimental conditions. To study the response of Saduria entomon to oxygen deficiency, a technique using aquarium experiments with different oxygen concentrations was designed. The prey species were collected in July-August using an Ekman-Birge grab. They were extracted in the laboratory to avoid rough handling in the field. $S$. entomon were collected using baited traps (dead fish) and maintained in a storage aquarium where they were fed dead fish or 
mussels. Brood-carrying females were not used in the experiments. The animals were placed in transparent aquaria (bottom area $121 \mathrm{~cm}^{2}$ ) with a $3 \mathrm{~cm}$ thick azoic sediment layer (sieved, $0.5 \mathrm{~mm}$ sand and clay, deepfrozen for $48 \mathrm{~h},-20^{\circ} \mathrm{C}$ ). The mean organic content (loss on ignition, $\%$ ) of the sediment was $0.3 \%$. These aquaria were submerged in larger $(60 \times 30 \times 29 \mathrm{~cm})$ holding tanks, one for the control aquaria (normoxia, $95 \%$ oxygen saturation) and one for the treatment aquaria with reduced oxygen contents. Reduced oxygen saturation in the water was achieved by $\mathrm{N}_{2}$ bubbling and kept constant by adding $\mathrm{N}_{2}$ if the oxygen level increased. The oxygen content was continually monitored with a YSI model 57 oxygen meter connected to a recorder. The oxygen meter was calibrated daily by Winkler titration. Circulation in the system was maintained by recirculating water at $0.21 \mathrm{~min}^{-1}$ through the aquaria by a peristaltic pump (ColePalmer). To avoid differences in oxygen saturation among the smaller experimental aquaria each small aquarium received oxygen-deficient water with a separate tube tipped with an injection needle. The oxygen saturation was gradually reduced simultaneously both for the prey and predators, in order to avoid a shock reaction due to sudden oxygen reduction. While reducing oxygen saturation the predators were kept in separate aquaria. In the normoxia treatment, the oxygen saturation was kept at approximately $95 \%$ by using aquarium air pumps, and was measured by a portable DO meter and by Winkler titration. All experiments were performed under $12: 12 \mathrm{~h}$ light: dark, 4 to $5 \%$ salinity and 12 to $15^{\circ} \mathrm{C}$. All experiments were run for approximately $60 \mathrm{~h}$ and the predators were starved for $48 \mathrm{~h}$ before each run. The prey species were allowed to acclimatize in the aquaria for a minimum of $5 \mathrm{~h}$ in normoxia before the oxygen level was reduced. The appropriate oxygen level was achieved after approximately $10 \mathrm{~h}$. For the predation treatment, 1 predator was used per aquarium to avoid competition between the predators. Control treatments without predators were run for controlling mortality due to factors other than predation. The aquaria were covered with a $0.5 \mathrm{~mm}$ mesh net to prevent the prey and predator from escaping to the surrounding water. For each treatment 5 replicates were run and statistically analysed with a 1 -way ANOVA. Inactive predators and those that moulted during the experiment were not included in the analysis.

Aquarium Expt 1. The first experiment was designed to test for changes in the predation efficiency of Saduria entomon [mean length ( $\pm \mathrm{SE}$ ) $37.4 \pm 0.7 \mathrm{~mm}$ ] with 15 Corophium volutator per aquarium (1327 ind. $\mathrm{m}^{-2}$ ) (mean length $4.7 \pm 0.1 \mathrm{~mm}$ ) as prey in 4 different oxygen treatments: 95 (normoxia), 50, 30 and $17 \%$ oxygen saturation (see Table 1).
Aquarium Expt 2. In the second experiment 30 Bathyporeia pilosa per aquarium (2654 ind. $\mathrm{m}^{-2}$ ) [mean length ( $\pm \mathrm{SE}$ ) $3.7 \pm 0.1 \mathrm{~mm}$ ] were used as prey organisms in 3 different oxygen treatments: 95, 50 and 35\% oxygen saturation. The mean length of Saduria entomon was $36.3 \pm 0.9 \mathrm{~mm}$ (see Table 2).

Prey abundances were chosen to match the natural densities in shallow areas in the northern Baltic Sea (Blomqvist \& Bonsdorff 1986, Mattila \& Bonsdorff 1989). At the end of the experiments water samples for Winkler titration were taken from each small aquarium. Subsequently the entire contents of the small aquaria were sieved through a $0.5 \mathrm{~mm}$ mesh and the remaining prey were counted. The position in the sediment and condition (swimming activity in normoxic water) of both the predator and remaining prey were recorded.

\section{RESULTS}

\section{Corophium volutator vs Saduria entomon}

The oxygen content during the experiments was stable. For details on hydrography see Table 1 . The survival rate of Corophium volutator (Fig. 1) in the control treatments was $>90 \%$, independent of oxygen content, with a mean mortality rate of $5 \%$ (Table 1 ). Significant predation effects $(p<0.01,1$-way ANOVA) were recorded when comparing each control of 95 , 50,30 and $17 \%$ oxygen saturation with the predation treatments in 95,50 and $30 \%$ oxygen. No significant

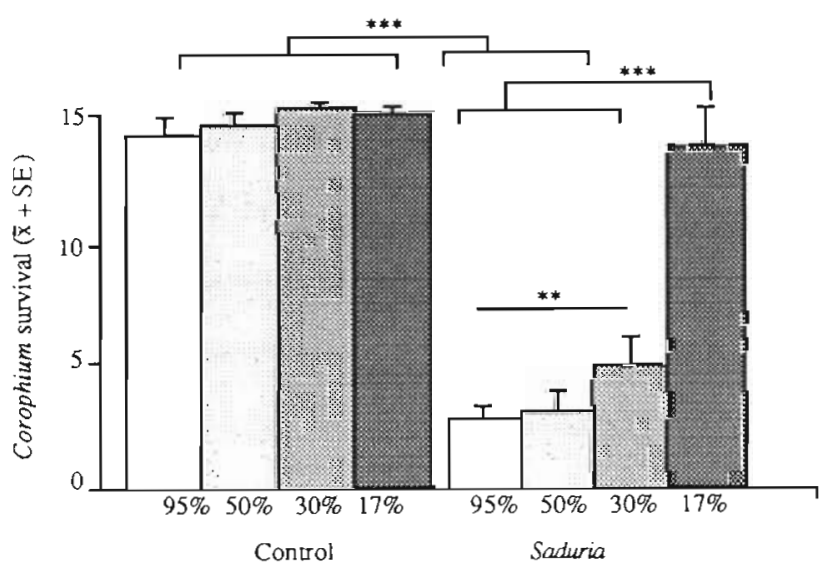

Fig. 1. Corophium volutator. Survival rate in aquarium Expt 1. Bars show the mean number of surviving $C$. volutator in each treatment. Treatments are: control for $95,50,30$ and $17 \%$ oxygen saturation, and predation (= Saduria) for 95, 50, 30 and $17 \%$ oxygen saturation. Significant differences were found between treatments connected by the end points of the horizontal lines in the figure $(\cdots p<0.01, \cdots p<0.05)$ 
Table 1. Experimental set-up, hydrographical conditions and results from Expt 1 studying changes in predation rate of Saduria entomon on Corophium volutator in $95,50,30$ and $17 \%$ oxygen saturation

\begin{tabular}{|c|c|c|c|c|c|c|c|c|}
\hline & \multicolumn{2}{|c|}{$95 \% \mathrm{O}_{2}$} & \multicolumn{2}{|c|}{$50 \% \mathrm{O}_{2}$} & \multicolumn{2}{|c|}{$30 \% \mathrm{O}_{2}$} & \multicolumn{2}{|c|}{$17 \% \mathrm{O}_{2}$} \\
\hline & Control & Sadunia & Control & Saduria & Control & Saduria & Control & Saduria \\
\hline No. of replicates & 5 & 5 & 5 & 5 & 5 & 5 & 5 & 5 \\
\hline No. S. entomon aquarium ${ }^{-1}$ & - & 1 & - & 1 & - & 1 & - & 1 \\
\hline S. entomon size $(\mathrm{mm} \pm \mathrm{SE})$ & - & $37 \pm 1.5$ & - & $37.6 \pm 1.2$ & - & $36.5 \pm 1.5$ & - & $38.4 \pm 1.6$ \\
\hline $\begin{array}{l}\text { No. C. volutator aquarium }{ }^{-1} \text { : } \\
\text { Start } \\
\text { Final }( \pm \mathrm{SE})\end{array}$ & $\begin{array}{c}15 \\
13.6 \pm 0.9\end{array}$ & $\begin{array}{c}15 \\
1.4 \pm 0.6\end{array}$ & $\begin{array}{c}15 \\
14 \pm 0.5\end{array}$ & $\begin{array}{c}15 \\
1.7 \pm 0.8\end{array}$ & $\begin{array}{c}15 \\
14.8 \pm 0.2\end{array}$ & $\begin{array}{c}15 \\
3.7 \pm 1.1\end{array}$ & $\begin{array}{c}15 \\
14.6 \pm 0.2\end{array}$ & $\begin{array}{c}15 \\
13.2 \pm 1.6\end{array}$ \\
\hline Survival $(\%)$ & 91 & 9.3 & 93 & 9.3 & 98 & 25 & 97 & 88 \\
\hline Initial C. volutator size $(\mathrm{mm} \pm$ & $4.8=$ & 0.2 & 4.7 & \pm 0.3 & $4.2 \pm$ & 0.15 & 4.8 & \pm 0.2 \\
\hline 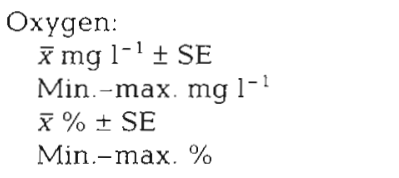 & $\begin{array}{r}10.1 \\
9.4- \\
94.8 \\
89\end{array}$ & $\begin{array}{l}0.07 \\
10.3 \\
0.68 \\
98\end{array}$ & $\begin{array}{r}5.2 \\
4.2 \\
49.5 \\
40\end{array}$ & $\begin{array}{l} \pm 0.08 \\
-6.2 \\
\pm 0.8 \\
-59\end{array}$ & $\begin{array}{r}3.1 \pm \\
2.8 \\
29.5 \\
27\end{array}$ & $\begin{array}{l}0.04 \\
-3.5 \\
\pm 0.5 \\
-34\end{array}$ & $\begin{array}{r}1.8 \pm \\
1.3 \\
16.7 \\
13\end{array}$ & $\begin{array}{l}0.05 \\
-2.0 \\
\pm 0.5 \\
-19\end{array}$ \\
\hline $\begin{array}{l}\text { Temperature: } \\
\bar{x}^{\circ} \mathrm{C} \pm \mathrm{SE} \\
\text { Min.-max. }{ }^{\circ} \mathrm{C}\end{array}$ & $\begin{array}{c}13.0 \\
13-\end{array}$ & & $\begin{array}{c}12.7 \\
12.2\end{array}$ & $\begin{array}{l} \pm 0.06 \\
-13.2\end{array}$ & $\begin{array}{l}13.0 \\
12.2\end{array}$ & $\begin{array}{r} \pm 0.2 \\
-14.3\end{array}$ & $\begin{array}{r}12.9 \\
12.6\end{array}$ & $\begin{array}{l}0.06 \\
-13.5\end{array}$ \\
\hline
\end{tabular}

predation effect was recorded for the predation treatment with $17 \%$ oxygen compared to the controls. When comparing the predation treatments significant differences were found between $95 \%$ and $30 \%$ ( $p<$ $0.05), 95 \%$ and $17 \%(\mathrm{p}<0.01), 50 \%$ and $17 \%(\mathrm{p}<$ $0.01)$ and $30 \%$ and $17 \%(p<0.01)$, with the lowest predation rate occurring in $17 \%$ oxygen saturation $188 \%$ survival of $C$. volutator).

\section{Bathyporeia pilosa vs Saduria entomon}

The oxygen content was stable during the experiment (Table 2). The survival rate of Bathyporeia pilosa (Fig. 2) in the control treatments was $>90 \%$, independent of the oxygen content, with a mean mortality rate of $5.2 \%$ (Table 2). Significant $(p<0.01)$ preclation effects were recorded when comparing each control of

Table 2. Experimental set-up, hydrographical conditions and results from Expt 2 studying changes in predation rate of Saduria entomon on Bathyporeia pilosa in 95,50 and $35 \%$ oxygen saturation

\begin{tabular}{|c|c|c|c|c|c|c|}
\hline & \multicolumn{2}{|c|}{$95 \% \mathrm{O}_{2}$} & \multicolumn{2}{|c|}{$50 \% \mathrm{O}_{2}$} & \multicolumn{2}{|c|}{$35 \% \mathrm{O}_{2}$} \\
\hline & Control & Saduria & Control & Saduria & Control & Saduria \\
\hline No. of replicates & 5 & 5 & 5 & 5 & 5 & 5 \\
\hline No. S. entomon aquarium ${ }^{-1}$ & - & 1 & - & 1 & - & 1 \\
\hline S. entomon size $(\mathrm{mm} \pm \mathrm{SE})$ & - & $35.2 \pm 1.5$ & - & $38.0 \pm 1.9$ & - & $35.8 \pm 1.2$ \\
\hline \multicolumn{7}{|l|}{ No. B. pilosa aquarium ${ }^{-1}$. } \\
\hline Start & 30 & 30 & 30 & 30 & 30 & 30 \\
\hline Final $( \pm \mathrm{SE})$ & $29 \pm 0.5$ & $12.3 \pm 3.4$ & $29 \pm 0.5$ & $12.2 \pm 3.1$ & $27.4 \pm 0.7$ & $21.7 \pm 4.0$ \\
\hline Survival $(\%)$ & 96 & 41 & 96 & 41 & 91 & 73 \\
\hline Initial B. pilosa size $(\mathrm{mm} \pm \mathrm{SE})$ & \multicolumn{2}{|c|}{-} & \multicolumn{2}{|c|}{$3.6 \pm 0.1$} & \multicolumn{2}{|c|}{$3.8 \pm 0.1$} \\
\hline \multicolumn{7}{|l|}{ Oxygen: } \\
\hline $\bar{x} \mathrm{mg} \mathrm{l}^{-1} \pm \mathrm{SE}$ & \multicolumn{2}{|c|}{$10.2 \pm 0.03$} & \multicolumn{2}{|c|}{$5.3 \pm 0.03$} & \multicolumn{2}{|c|}{$3.7 \pm 0.08$} \\
\hline Min.-max. $m g !^{-1}$ & \multicolumn{2}{|c|}{$10.0-10.3$} & \multicolumn{2}{|c|}{$5.0-5.6$} & \multicolumn{2}{|c|}{$3.3-4.3$} \\
\hline $\bar{x} \% \pm \mathrm{SE}$ & \multicolumn{2}{|c|}{$96.5 \pm 0.3$} & \multicolumn{2}{|c|}{$50.2 \pm 0.3$} & \multicolumn{2}{|c|}{$35.9 \pm 0.8$} \\
\hline Min-max. \% & \multicolumn{2}{|c|}{$95-98$} & \multicolumn{2}{|c|}{$47-53$} & \multicolumn{2}{|c|}{$32-42$} \\
\hline \multicolumn{7}{|l|}{ Temperature: } \\
\hline $\bar{x}^{\circ} \mathrm{C} \pm \mathrm{SE}$ & \multicolumn{2}{|c|}{$13.0 \pm 0$} & \multicolumn{2}{|c|}{$13.4 \pm 0.1$} & \multicolumn{2}{|c|}{$14.0 \pm 0.1$} \\
\hline Min $-\max .{ }^{\circ} \mathrm{C}$ & \multicolumn{2}{|c|}{$13-13$} & \multicolumn{2}{|c|}{$12.2-14.5$} & \multicolumn{2}{|c|}{$13.5-15.5$} \\
\hline
\end{tabular}




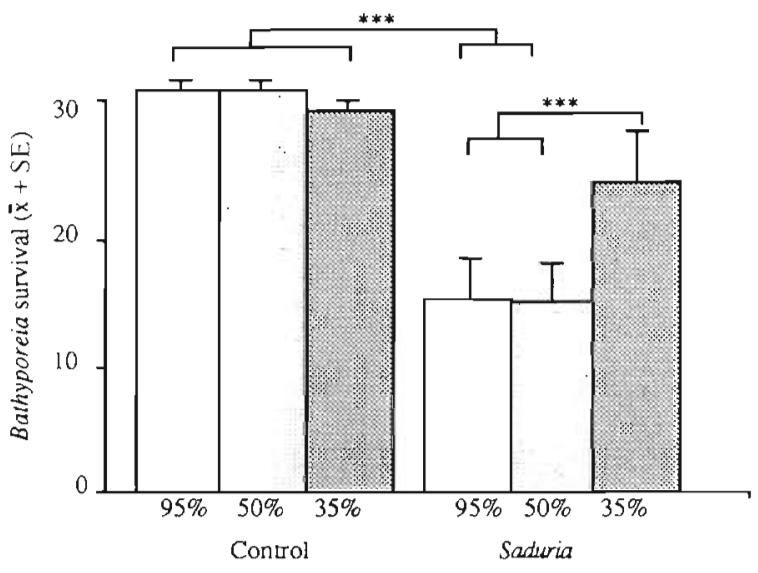

Fig. 2. Bathyporeia pilosa. Survival rate in aquarium Expt 2. Bars show the mean number of surviving $B$. pilosa in each treatment. Treatments are: control for 95,50 and $35 \%$ oxygen saturation, and predation (= Saduria) for 95,50 and $35 \%$ oxygen saturation. Significant differences were found between treatments connected by the end points of the horizontal lines in the figure $(\cdots p<0.01, \cdots p<0.05)$

95, 50 and $35 \%$ oxygen with the predation treatments in 95 and $50 \%$ oxygen saturation. For the predation effects in $35 \%$ oxygen no significant effects were detected. When comparing the different predation treatments significant differences were found between $95 \%$ and $35 \%(p<0.05)$ and between $50 \%$ and $35 \%$ $(\mathrm{p}<0.01)$, with the lowest predation rate occurring in $35 \%$ oxygen saturation ( $73 \%$ survival of $B$. pilosa).

\section{General behaviour of the test organisms}

Both the prey and predators were in good condition (swimming activity high when placed in normoxic water) at the end of every treatment in Expt 1 . Corophium volutator was evenly distributed in the top layer of the sediment with tubes visible at the sediment surface. In the treatment with $17 \%$ oxygen saturation Saduria entomon emerged completely and was standing upon the sediment ventilating its gills. After Expt 2, Bathyporeia pilosa were mainly found at $2 \mathrm{~cm}$ depth in the sediment, and the individuals found at the end of the treatments were all in good condition, as well as the predators. The behaviour of the experimental animals was not studied in detail, to avoid disturbing their nocturnal activity.

\section{DISCUSSION}

Changes in the physical environment lead to altered physiological and ecological couplings which cause the physiologically affected organisms to change their behaviour. These changes might distort the ecological balance between a predator and prey. Because of the low species diversity in the brackish Baltic Sea, the functional response (rate of predation) of a predator may be a major determinant of the structure of the entire community (Abrams et al. 1990). Changes in the interaction between a predator and prey can be illustrated by examining the rate of predation at different oxygen levels, i.e. on a stress gradient (Fig. 3). In this study the rate of predation changed with increasing sublethal abiotic stress, shown as a decrease in predation. The time spent foraging is expected to change due to increased stress (Abrams 1982), and invertebrates have been shown to vary foraging time in relation to risks (Menge 1974). The different effects on the predation rates of Saduria entomon given 2 different prey types indicates that too high a foraging effort is needed for more active prey (i.e. Bathyporeia pilosa) under stressful conditions, even if the prey abundance is relatively high, facilitating high encounter rates $(\mathrm{n}=$ $30 \mathrm{~B}$. pilosa compared to $\mathrm{n}=15$ Corophium volutator per aquarium). C. volutator is more easily exhausted by swimming compared to the more active and disturbance-tolerant $B$. pilosa, thus making $C$. volutator easier to hunt. However, both species are potentially important as food for $S$. entomon. Oxygen deficiency might lead to changes in prey behaviour, which might increase their susceptibility to predation (Pihl et al. 1992), but this was not recorded for $C$. volutator and $B$. pilosa in the present study, where a pronounced predation in low oxygen treatments did not occur. It is not clear whether, in more tolerant crustaceans, hypoxia reduces the normal metabolic rate as occurs in bivalves and annelids (Zebe 1991). However, the present study was based on short-term experiments and it is difficult

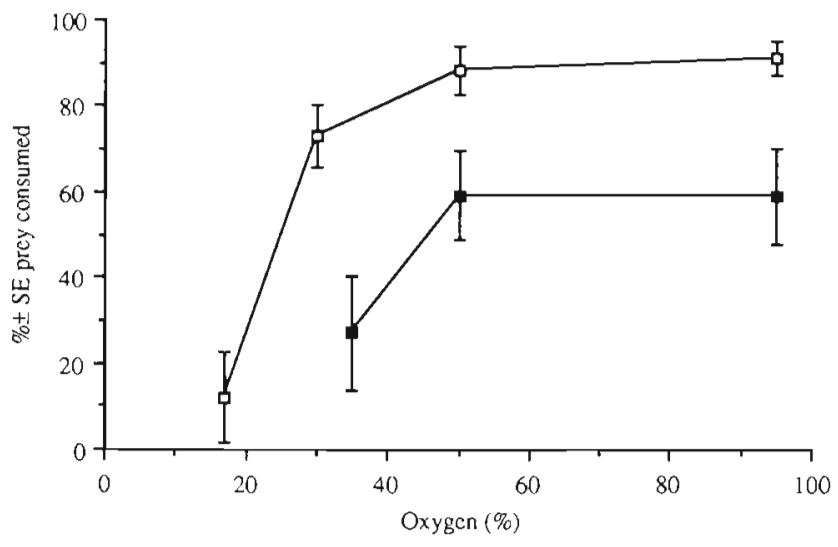

Fig. 3. Rate of predation by Saduria entomon when given a constant number of prey (Corophium volutator, $\mathbf{D}_{\text {; B Bthy- }}$ poreia pilosa, - at different oxygen levels. The response is illustrated as percent of prey consumed 
to say if changes in metabolic rate (here reflected by number of prey consumed) are detectable under these circumstances, as $S$. entomon is relatively inactive with a low metabolic rate (Hagerman \& Szaniawska 1988). The oxygen concentration was reduced in the water according to the methods used by Rosenberg et al. (1991) and not by increasing the biological oxygen demand (e.g. organic enrichment). The tolerance of benthic infauna to hypoxia may not be identical if low oxygen concentration is initiated within the sediment (Rosenberg et al. 1991).

In Expt 1 (Corophium volutator as prey) a change in predator behaviour was registered at $17 \%$ oxygen saturation (severe hypoxia). Under experimental conditions Saduria entomon is able to utilize all available oxygen but is forced to emerge from the sediment at low oxygen saturation due to the slow water transport through the interstitial pore system (Hagerman \& Szaniawska 1988 ). At $17 \%$ oxygen saturation $S$. entomon was no longer buried in the sediment but instead was standing on the sediment with its gills above the sediment surface, thus increasing ventilation. The behavioural reactions of the test organisms to oxygen deficiency are of vital importance, and more detailed investigations are needed to understand changes in the relationship between a prey and predator.

The recovery of macrobenthic assemblages from hypoxia should be largely structured by the relationship between timing of the return to normoxic conditions and species life history. It is important to consider the tolerance of larvae and adults to hypoxia when assessing the recolonization success of the species colonizing the hypoxia-affected habitats (Llansó 1991). In a study comparing 2 different habitats, one exposed (regulated by physical factors) and one sheltered (regulated by biotic factors), Duineveld et al. (1991) found a difference in recovery after severe oxygen deficiency. The benthic community rapidly regained its former structure in the more exposed area, but in a more protected muddy-sand habitat a similar event may lead to more permanent changes due to the importance of biological interactions (Duineveld et al. 1991). In the Baltic Sea the uppermost littoral zones and the deeper soft bottoms can be characterized as short-lived, unpredictable habitats. The littoral zone is subject to severe natural stressors, while the deeper parts (below the thermo-and halocline) are irregularly affected by oxygen deficiency (Leppäkoski \& Bonsdorff 1989) As opportunism seems to be important in ecosystems subjected to multiple natural and maninduced perturbations (Desprez et al. 1992), predation effects on opportunistic species (e.g. Corophium volutator) are important (see Bonsdorff 1989 and references therein). Saduria entomon is known to affect macrofaunal colonization under normoxic conditions, by acting both as a disturber (bioturbation) and as a predator (Aarnio et al. 1991, Ejdung \& Bonsdorff 1992). Because $S$. entomon is very tolerant to both hypoxia and anoxia and is also known to survive starvation for longer periods of time, it is possible for this predator to be present during the recovery. While C. volutator utilize an opportunistic migration pattern (Bonsdorff \& Österman 1985), S. entomon could alter C. volutator population size and dynamics. The different behaviour of the prey species changes the availability of the prey during progressive hypoxia. According to these results Bathyporeia pilosa, being a more active species and thus more difficult to locate, is less affected by predation during hypoxia compared to $C$. volutator. Hypothetically, an increase in the population size of $B$. pilosa could be expected if this species were able to maintain its reproductive output under hypoxic conditions. More detailed studies on the tolerance of the prey species to hypoxia are needed to fully understand the effect of changed predation pressure during and after hypoxic stress. As hypoxia induces changes in interactions between species it could influence species composition, expressed as decreased diversity, leading to an impoverishment of the benthic community structure. This could lead to simplified interactions between different trophic levels, affecting the dynamic equilibrium (Bonsdorff 1985) of a community.

Acknowledgements. I thank R. Kristoffersson and P.-L. Kuosa (University of Helsinki) for lending me laboratory equipment and for advice on methods. I am also grateful for practical advice from R. Rosenberg and B. Hellman (University of Göteborg Marine Research Station). Husö Biological Station provided me with excellent laboratory facilities. I also thank E. Bonsdorff for experimental ideas and for advice and comments on my work and A. Norkko for help with the experimental set-up. This work was funded by the Academy of Finland.

\section{LITERATURE CITED}

Aarnio. K., Sandherg, E. Bonsdorff, E. (1991). Benthic predation on shallow-water macro- and melofauna in the Baltic Sea: an experimental comparison between Pomatoschistus minutus (Pisces) and Saduria entomon (Crustacea). Annls zool. fenn. 28: 41-48

Abrams, P. A. (1982). Functional responses of optimal foragers. Am. Nat. 120: 382-390

Abrams, P. A., Hill, C., Elmgren, R. (1990). The functional response of the predatory polychaete. Harmothoe sarsi, to the amphipod, Pontoporeia affinis. Oikos 59:261-269

Baden, S. P., Loo, L. O., Pihl, L., Rosenberg, R. (1990). Effects of eutrophication on benthic communities including fish: Swedish west coast. Ambio 19: 113-122

Blomqvist, E. M. Bonsdorff, E. (1986). Spatial and temporal variations of benthic macrofauna in a sandbottom area on Aland, northern Baltic Sea. Ophelia, Suppl. 4: 27-36 
Bonsdorff, E. (1985). Recovery potential of the fauna of brackish-water softbottoms and marine intertidal rockpools. Ph.D. thesis, ISBN 951-649-108-1, A.bo Akademi University, Finland

Bonsdorff, E. (1989). Infaunal colonization and its dependence on environmental variation - experimental evidence from the northern Baltic Sea. In: Ryland, J. S., Tyler, P. A. (eds.) Proc. 23rd Eur. Mar. Biol. Symp. Olsen \& Olsen, Fredensborg, p. 349-356

Bonsdorff, E., Aarnio, K., Sandberg, E. (1991). Temporal and spatial variability of zoobenthic communities in archipelago waters of the northern Baltic Sea - consequences of eutrophication? Int. Rev. ges. Hydrobiol. 76: 433-449

Bonsdorff, E., Österman, C.-S. (1985). The establishment, succession and dynamics of a zoobenthic community - an experimental study. In: Gibbs, P. E. (ed.) Proc. 19th Eur. Mar. Biol. Symp. Cambridge University Press, Cambridge, p. $287-297$

Breitburg, D. L. (1992). Episodic hypoxia in Chesapeake Bay: interacting effects of recruitment, behavior, and physical disturbance. Ecol. Monogr. 62: 525-546

Cederwall, H., Elmgren, R. (1990). Biological effects of eutrophication in the Baltic Sea, particularly the coastal zone. Ambio 19: 109-112

Dahl, E. (1973). Ecological range of Baltic and North Sea species. Oikos, Suppl. 15: 85-90

Desprez, M., Rybarczyk, H., Wilson, J. G., Ducrotoy, J. P.. Sueue, F., Olivesi, R., Elkaim, B. (1992). Biological impact of eutrophication in the Bay of Somme and the induction and impact of anoxia. Neth. J. Sea Res. 30: 149-159

Duineveld, G. C. A., Kunitzer, A., Nierman, U., de Wilde, P. A. W. J., Gray, J. S. (1991). The macrobenthos of the North Sea. Neth. J. Sea Res. 28: 53-65

Ejdung, G., Bonsdorff, E. (1992). Predation on the bivalve Macoma balthica by the isopod Saduria entomon: laboratory and field experiments. Mar. Ecol. Prog. Ser. 88 : $207-214$

Elmgren, R. (1989). Man's impact on the ecosystem of the Baltic Sea: energy flows today and at the turn of the century. Ambio 18: 326-332

Fenchel, T., Kofoed, L. H., Lappalainen, A. (1975). Particle size-selection of two deposit feeders; the amphipod Corophium volutator and the prosobranch Hydrobia ulvae. Mar. Biol. 30: 119-128

Fish, J. D., Preece, G. S. (1970). The annual reproductive patterns of Bathyporeia pilosa and B. pelagica (Crustacea: Amphipoda). J. mar. biol. Ass. U.K. 50: 475-488

Gray, J. S. (1992). Eutrophication in the sea. In: Colombo, G. C., Ferrari, I., Ceccherelli, V. U., Rossi, R. (eds.) Proc. 23rd Eur Mar Biol. Symp. Olsen \& Olsen, Fredensborg, p. $3-13$

Hagerman, L., Oksama, M. (1985). Haemocyanin concentration, carrying capacity and haemolymph $\mathrm{pH}$ under hypoxia in Mesidothea entomon (L.) (Isopoda, Crustacea). Ophelia 24: 47-52

Hagerman, L., Szaniawska, A. (1988). Respiration, ventilation and circulation under hypoxia in the glacial relict Saduria (Mesidotea) entomon. Mar. Ecol. Prog. Ser. 47: 55-63

Hagerman, L., Szaniawska, A. (1990). Anaerobic metabolic strategy of the glacial relict isopod Saduria (Mesidotea) entomon. Mar. Ecol. Prog. Ser. 59: 91-96

Hill, C., Elmgren, R. (1992). Predation by the isopod Saduria entomon on the amphipods Monoporeia affinis and Pontoporeia femorata: experiments on prey vulnerability. Oecologia 91: 153-156

Jensen, K. T., Kristensen, L. D. (1990). A field experiment on competition between Corophium volutator (Pallas) and
Corophium arenarium Crawford (Crustacea: Amphipoda): effects on survival, reproduction and recruitment. J. exp. mar. Biol. Ecol. 137: 1-24

Jørgensen, B. B. (1980). Seasonal oxygen depletion in the bottom waters of a Danish fjord and its effect on the benthic community. Oikos 34:68-76

Kemp, W. M., Sampou, P., Caffrey, J., Mayer, M., Henriksen, K., Boynton, W. R. (1990). Ammonium recycling versus denitrification in Chesapeake Bay sediments. Limnol. Oceanogr. 35: 1545-1563

Larsson, U., Elmgren, R., Wulff, F. (1985). Eutrophication and the Baltic Sea: causes and consequences. Ambio 14: 9-14

Leonardsson, K. (1986). Growth and reproduction of Mesidotea entomon (Isopoda) in the northern Baltic Sea. Holarct. Ecol. 9: 240-244

Leonardsson, K. (1991). Effects of cannibalism and alternative prey on population dynamics of Saduria entomon (Isopoda). Ecology 72: 1273-1285

Leonardsson, K., Bengtsson, А., Linne'r, J. (1988). Sizeselective predation by fourhorn sculpin, Myoxocephalus quadricornis (L.) (Pisces) on Mesidotea entomon (L.) (Crustacea, lsopoda). Hydrobiologia 164: 213-220

Leppäkoski, E., Bonsdorff, E. (1989). Ecosystem variability and gradients. Examples from the Baltic Sea as a background for hazard assessment. In: Landner, L. (cd.) Chemicals in the aquatic environment. Springer-Verlag, Berlin, p. $6-58$

Llansó, R. J. (1991). Tolerance of low dissolved oxygen and hydrogen sulfide by the polychaete Streblospio benedictii (Webster). J. exp. mar. Biol. Ecol. 153: 165-178

Mattila, J., Bonsdorff, E. (1989). The impact of fish predation on shallow soft bottoms in brackish waters (SW Finland); an experimental study. Neth. J. Sea Res. 23: 69-81

Menge, J. L. (1974). Prey selection and foraging period of the predaceous rocky intertidal snail, Acanthina punctulata. Oecologia 17: 293-316

Mettam, C. (1989). The life cycle of Bathyporeia pilosa Lindström (Amphipoda) in a stressful, low salinity environment. In: Ros, J. D. (ed.) Topics in marine biology. Scientia mar. 53: 543-550

Möller, P., Rosenberg, R. (1982). Production and abundance of the amphipod Corophium volutator on the west coast of Sweden. Neth. J. Sea Res. 16: 127-140

Nehring, D., Matthäus, W. (1991). Current trends in hydrography and chemical parameters and eutrophication in the Baltic Sea. Int Rev. ges. Hydrobiol. 76: 297-316

Nicolaisen, W., Kanneworff, E. (1983). Annual variations in vertical distribution and density of Bathyporeia pilosa Lindström and Bathyporeia sarsi Watkin at Julebæk (North-Sealand, Denmark). Ophelia 22: 237-251

Pearson, T H., Rosenberg, R. (1978). Macrobenthic succession in relation to organic enrichment and pollution of the marine environment. Oceanogr. mar. biol. A. Rev. 16: 229-311

Pihl, L. (1989). Effects of oxygen depletion on demersal fish in coastal areas of the south-east Kattegat. In: Ryland, J. S., Tyler, P. A. (eds.) Proc. 23rd Eur. Mar. Biol. Symp. Olsen \& Olsen, Fredensborg, p. 431-439.

Pihl, L., Baden, S. P., Diaz, R. J. (1991). Effects of periodic hypoxia on distribution of demersal fish and crustaceans. Mar. Biol. 108: 349-360

Pihl, L., Baden, S. P., Diaz, R. J., Schaffner, L. C. (1992) Hypoxia-induced structural changes in the diet of bottomfeeding fish and Crustacea. Mar. Biol. 112: 349-361

Rosenberg, R., Hellman, B., Johansson, B. (1991). Hypoxic tolerance of marine benthic fauna. Mar Ecol. Prog. Ser 79 $127-131$ 
Rosenberg, R., Loo, L. O. (1988). Marine eutrophication induced oxygen deficiency: effects on soft bottom fauna, western Sweden. Ophelia 29: 213-225

Sandberg, E., Bonsdorff, E. (1990). On the structuring role of Saduria entomon (L.) on shallow water zoobenthos. Annls zool. fenn. 27: 279-284

Sandberg, E, Bonsdorff, E. (1993). Competition for food between predators of marine and limnic origin - experiments with Saduria entomon (Isopoda) and Libellula quadrimaculata (Odonata). In: Bjørnestad, E., Hagerman, L., Jensen, K. (eds.) Proc. 12th Baltic Marine Biologists Symp. Olsen \& Olsen, Fredensborg, p. 141-144

Seitzinger, S. P., Nixon, S. W., Pilson, M. E. Q. (1984). Denitrification and nitrous oxide production in a coastal marine

This article was presented by J. Gray, Oslo, Norway ecosystem. Limnol. Oceanogr. 29: 73-83

Weigelt, M. (1991). Short-and long-term changes in the benthic community of the deeper parts of Kiel Bay (Western Baltic) due to oxygen depletion and eutrophication. Meeresforsch. 33: 197-224

Winn, R. N., Knott, D. M. (1992). An evaluation of the survival of experimental populations exposed to hypoxia in the Savannah River estuary. Mar. Ecol. Prog. Ser. 88: $161-179$

Visman, B. (1991). Physiology of sulfide detoxification in the isopod Saduria (Mesidotea) entomon. Mar. Ecol. Prog. Ser. 76: $283-293$

Zebe, E. (1991). Arthropods. In: Bryant, C. (ed.) Metazoan life without oxygen. Chapman and Hall, London, p. 219-237

Manuscript first received: May 1, 1993

Revised version accepted: August 25, 1993 